\title{
CATUR GURU DALAM PEMAKNAAN HARI SUCI SARASWATI PERSPEKTIF FILSAFAT PENDIDIKAN HINDU
}

\author{
I Nyoman Sidi Astawa
}

Institut Agama Hindu Negeri Tampung Penyang Palangkaraya

bawiayahfda@gmail.com

\section{Riwayat Jurnal - \\ Artikel diterima : - \\ Artikel direvisi : :- \\ Artikel disetujui : :-}

\begin{abstract}
Abstrak
Tulisan ini bertujuan untuk mengkaji dari aspek yang berbeda terhadap hari suci Saraswati yakni mengenai nilai-nilai pendidikan dan catur guru dalam hari suci Saraswati. Nilai-nilai pendidikan Hindu yang terdapat dalam hari suci Saraswati secara garis besarnya atau pokok-pokoknya sesuai dengan tri kerangka dasar agama Hindu. Dalam pemaknaan hari suci Saraswati terdapat pula ajaran agama Hindu tentang guru yang terdiri atas Tuhan (Swadyaya), Pemerintah (Wisesa), Guru di sekolah (Pengajian) dan Orang Tua (rupaka) yang disebut dengan istilah catur guru.
\end{abstract}

Kata kunci : catur guru, hari suci Saraswati, filsafat pendidikan Hindu.

\section{Pendahuluan}

Hari raya atau hari suci untuk memuja Dewi Saraswati merupakan salah satu hari suci yang dimiliki umat Hindu di Indonesia khususnya dan di dunia umumnya. Pemujaan Dewi Saraswati sebagai dewi ilmu pengetahuan ditentukan berdasarkan hari-hari tertentu yang sesuai dan hari tersebut dijadikan sebagai hari suci atau hari raya. Hari raya atau hari suci merupakan suatu bentuk implementasi ajaran-ajaran agama termasuk hari suci Saraswati yang diperingati di Indonesia. Dalam hari suci tersebut terdapat banyak simbol-simbol yang memiliki makna yang membentuk sistem dalam hari suci tersebut. Pernyataan tersebut tepat karena menurut Geertz (1992:53) bahwa "Yang membentuk sebuah sistem religius adalah serangkaian simbol sakral yang terjalin menjadi sebuah keseluruhan tertentu yang teratur." Hari suci Saraswati dijadikan sebagai hari suci dalam Hindu sudah tentu memiliki makna atau nilai ajaran yang ingin disampaikan terutama 
mengenai nilai pendidikan Hindu dan yang terkait dengan pendidikan Hindu yakni catur guru.

Pengkajian ilmiah terhadap hari suci Saraswati ada beberapa seperti yang dilakukan oleh Fadillah (2015) yang melihat aspek komunikasi dalam hari suci tersebut dengan pendekatan atau perspektif etnografi. Suarnada (2015) mengkaji mengenai pemahaman umat Hindu di Sulawesi Tengah terhadap hari Suci Saraswati. Selain tersebut ada juga kajian ilmiah yang lainnya. Pada umumnya semua kajian ilmiah yang telah dilakukan terhadap hari suci Saraswati belum menyentuh pada makna hari saraswati terkait dengan nilai pendidikan dan makna catur guru yang terdapat didalamnya. Tulisan ini bertujuan untuk mengkaji dari aspek yang berbeda terhadap hari suci Saraswati yakni mengenai nilai-nilai pendidikan dan catur guru dalam hari suci Saraswati.

\section{Pembahasan}

\subsection{Nilai-nilai Pendidikan Hindu yang terkandung dalam Saraswati}

Masalah nilai-nilai pendidikan
agama Hindu dalam pelaksanaan
Saraswati telah tersurat pada uraian di
atas. Dalam setiap aspek pelaksanaan hari

suci Saraswati sudah pasti mengandung makna atau nilai pendidikan yang akan diajarkan kepada umat Hindu. Persoalan pokok dalam pendidikan Hindu yaitu bagaimana manusiah putrah dapat ditingkatkan kualitas sraddha dan bhaktinya. Pendidikan agama Hindu Pada dasarnya dapat diartikan sebagai suatu bantuan yang diberikan manusia untuk mengenal dan memahami ajaran agama Hindu (Awanta, dkk, 2001:53). Secara umum dan pada intinya nilai-nilai ajaran atau pendidikan agama Hindu mencakup Pendidikan Tattwa, Etika dan Ritual. Ketiganya nilai tersebut menjadi dasar dari ajaran agama Hindu. Walaupun, secara utuh nilai pendidikan Hindu mencakup segala aspek dalam kehidupan ini. Hal itu menginggat kitab suci Hindu yaitu Weda sebagai Sumber Pengetahuan dan cikal-bakal dari agama-agama yang ada di dunia ini. Akan tetapi dalam kesempatan ini akan bahas mengenai nilai-nilai pendidikan Hindu secara Garis besarnya atau pokok-pokoknya sesuai dengan tri kerangka dasar agama Hindu.

\subsubsection{Nilai Pendidikan Tatwa}

Nilai pendidikan tattwa yang terkandung dalam hari suci Saraswati 
terdiri atas pendidikan teologi atau ketuhanan dan pendidikan filosofi.

a. Teologi (Ketuhanan)

Hari suci Saraswati seperti halnya hari suci yang lainnya dalam praktiknya selalu diikuti oleh kegiatan pemujaan terhadap aspek Tuhan dalam ajaran agama Hindu. Hari suci Saraswati merupakan waktu khusus yang diperuntukkan untuk pemujaan Dewi Saraswati yang diyakini oleh umat Hindu sebagai Dewi Ilmu Pengetahuan. Dewi Saraswati merupakan aspek Tuhan dalam fungsinya sebagai sumber ilmu pengetahuan. Pelaksanaan perayaan hari suci Saraswati mendidik umat Hindu untuk mengenal Tuhan dalam aspeknya sebagai penguasa ilmu pengetahuan. Pendapat tersebut sejalan dengan gagasan Ngurah,dkk (2006:188) bahwa "Hari suci Saraswati merupakan manifestasi-Nya sebagai Dewanya ilmu pengetahuan, kekuatan Hyang Widhi dalam manifestasinya ini, dilambangkan dengan seorang dewi membawa alat musik, genitri, pustaka suci, teratai serta duduk di atas angsa". Umat Hindu diajarkan untuk selalu ingat bahwa selain diciptakan oleh Tuhan, manusia juga telah dibekali dan diberikan tuntunan bagaimana manusia hidup di alam ini. Gagasan tersebut sesuai dengan pendapat (Suhardana, 2010:36) bahwa :

"Beliaulah yang menciptakan alam semesta dengan segenap isinya ini, kemudian memelihara dan melindunginya dan akhirnya juga melebur atau mengembalikan ke dalam bentuk asalnya. Dinyatakan sebagai guru karena Tuhan adalah pembimbing utama bagi umat manusia yang tidak ada bandingannya".

Gagasan dan pendapat tersebut jelas menunjukkan adanya upaya pendidikan tentang memahami konsep ketuhanan agama Hindu dalam hari suci Saraswati. Hal itu terbukti dengan adanya pemujaan dewi Saraswati sebagai aspek atau fungsi Tuhan penguasa ilmu pengetahuan bukan Dewa Brahma yang diketahui sebagai aspek Tuhan dalam mencipta.

b. Filosofis

Perayaan hari suci Saraswati memiliki hakekat atau makna di dalamnya. Hakekat pokoknya dapat dinyatakan bahwa dalam perayaan hari suci Saraswati memiliki hakekat atau makna sosial dan makna individual. 
Makna sosial karena ada kecendrungan orang melakukan atau merayakan hari suci Saraswati bersangkut paut dengan orang lain atau berorientasi pada orang lain. Orang merayakan hari suci Saraswati karena merasa dirinya adalah bagian dari umat beragama Hindu. Oleh karena itu, pelaksanaan hari suci Saraswati mendidik umat Hindu untuk menjalani kehidupan sosial dan supaya menemukan kesadaran di dalam dirinya bahwa dalam kehidupan ini, dirinya merupakan bagian dari yang lain atau manusia lainnya. Kesadaran yang demikian akan memupuk rasa persatuan dan kebersamaan dalam kehidupan untuk saling mengahrgai, menolong dan melindungi satu dengan yang lainnya. Makna Individual dalam hari suci Saraswati ialah seseorang melaksanakan upacara Saraswati pada hakekatnya merupakan hubungan antara manusia dengan yang dipuja yakni dewi Saraswati atau aspek Tuhan dalam menguasai ilmu pengetahuan yang ada. Manusia berusaha untuk memperoleh berkat berupa ilmu pengetahuan guna mendapatkan kesejahteraan, kesehatan dan kebahagiaan dalam kehidupan dirinya.

\subsubsection{Nilai Pendidikan Susila}

Pelaksanaan perayaan hari suci saraswati memiliki suatu tata aturan tertentu yang telah ditetapkan oleh para pencetus atau leluhur umat Hindu. Tata aturan tersebut memperlihatkan bahwa ada nilai-nilai pendidikan susila yang hendak ditanamkan melalui pelaksanaan perayaan hari suci ini. Beberapa aturan tersebut misalnya tidak boleh membaca buku pada waktu tertentu, berpuasa, monobrata dan pemujaan yang tentunya dalam agama Hindu terkait dengan konsentrasi atau pemusatan pikiran. Bersembahyang yang di dalamnya terdapat usaha untuk memfokuskan pikiran kepada yang dipuja, yakni Dewi Saraswati merupakan suatu pendidikan untuk mengendalikan pikiran. Pengendalian pikiran menjadi suatu hal yang penting dalam kehidupan manusia. Dengan pikiran yang terkendali, maka manusia dapat menyucikan pikiran untuk selalu berpikir yang baik sesuai dengan ajaran manacika dalam Tri Kaya Parisudha dalam susila Hindu. Selain persembahyanagn dan meditasi dalam melaksanakan hari suci Saraswati juga ada aturan bahwa seseorang perlu 
melakukan monobrata atau mengendalikan perkataan.

Kegiatan monobrata merupakan suatu usaha atau pendidikan susila terkait dengan aspek vacika dalam Tri Kaya Parisudha yakni pensucian perkataan. Pengendalian perkataan yang dilakukan sebagai salah satu bentuk aturan yang ada dalam memperingati hari suci Saraswati merupakan usaha untuk mengendalikan perkataan, sehingga dengan kemampuan yang diperolehnya nanti dapat mengarahkan supaya perkataan selalu diatur atau dikendalikan untuk mengarah kepada hal-hal yang baik. Dalam pelaksanan hari suci ini terdapat pendidikan untuk melakukan suatu tindakan mengikuti atauran-aturan yang baik. Dalam hal ini, misalnya tidak boleh membaca merupakan suatu upaya untuk mendisiplinkan tindakan manusia supaya tindakan sesuai dengan susila. Tidak boleh membaca secara logika bahwa peringatan sumber ilmu pengetahuan tersimpan dalam buku, sehingga pada saat hari suci sebagai hari ilmu pengetahuan buku dikumpulkan dengan baik karena dianggap sebagai stana bagi dewi Ilmu Pengetahuan yang akan dipuja pada saat hari itu. Oleh karena itu, secara etika tidak baik apabila manusia membaca buku pada saat dilakukannya pemujaan Dewi Saraswati.

\subsubsection{Nilai Pendidikan Upacara}

Upacara sering dipahami sebagai tindakan atau kegiatan umat beragama dalam kaitannya dengan kewajiban sosial keagamaan. Pemahaman tersebut tentunya benar tetapi dalam ajaran Hindu pemahaman tersebut belum konprehensip. Upacara dalam ajaran Hindu tidak hanya sekedar kewajiban sosial atau kewajiban keagamaan tetapi juga merupakan suatu metode atau jalan untuk berusaha mendekatkan diri kepada Tuhan beserta manifestasinya. Pendapat tersebut sejalan dengan pendapat Wijayananda (2004:49) yang menegaskan mengenai upacara yakni "dengan keseimbangan, keharmonisan, dan keselarasan dalam diri kita mendekatkan diri dengan Tuhan Yang Maha Esa". Pendapat lain menyatakan bahwa dari sudut filsafatnya upacara ialah cara-cara melakukan hubungan antara atman dengan paramaatman, antara manusia dengan Hyang Widhi serta semua manifestasinya,... (Parisada Hindu Dhrama,2002:54). Pendapat Ngurah, dkk (2006:147) tentang pengertian upacara 
menyatakan bahwa" Kata upacara berasal dari bahasa Sanskerta berarti mendekati. Dalam kegiatan upacara agama diharapkan terjadi suatu upaya untuk mendekatkan diri kepada Hyang Widhi Wasa, Kepada sesama manusia, kepada alam lingkungan, pitara maupun rsi." Berdasarkan pendapat tersebut maka jelas hari scui Saraswati memiliki nilai pendidikan upacara karena dalam pelaksanaannya terdapat usaha untuk mendekatkan diri dengan yang dipuja.

\subsubsection{Seni}

Perayaan hari suci Saraswati dalam praktiknya memiliki beberapa aspek seni. Wina yang dipegang pada salah satu tangan dewi Saraswati merupakan simbul dari seni buadaya. Simbol seni budaya tersebut memberikan pendidikan kepada manusia bahwa dalam kehidupannya setiap perbuatan harus diiringi dengan suatu seni guna menyeimbangkan kehidupan supaya manusia mendapatkan kebahagiaan dalam dunia. Pelaksanaan hari suci Saraswati sebagai bentuk pemujaan kepada Tuhan dalam wujud Dewi Saraswati yakni sebagai simbol ilmu pengetahuan menunjukkan adanya suatu kreatifitas seni yang didasarkan pada satyam (kebenaran), siwam (kebaikan), dan sundaram (keindahan). Seni yang digunakan tersebut menjadi suatu cara atau metode untuk mencoba atau berusaha mendekati Tuhan melaui aspekaspeknya. Manusia mencoba memahami Tuhan sebagai penguasa yang tak terpikirkan dan tidak berwujud untuk kemudian diwujudkan berdasarkan konsep-konsep tentang Tuhan dalam bentuk atau wujud Dewi Saraswati dengan cita rasa seni yang mengikuti prinsip satyam, sivam, dan sundaram.

\subsubsection{Mantra}

Mantra merupakan salah satu aspek penting dalam setiap perayaan hari suci pada umumnya termasuk hari suci Saraswati. Mantra disetiap hari suci terdapat mantra yang sama dan juga terdapat mantra yang khusus. Mantra yang sama merupakan mantra-mantra yang umum mengikuti tata aturan pemujaan di Indonesia. Mantra khusus untuk digunakan dalam hari suci Saraswati ialah mantra pemujaan kepada dewi Saraswati aspek Tuhan sebagai pencipta dan penguasa ilmu pengetahuan. Mantra yang ditujukkan kepada dewi Saraswati merupakan mantra ista dewata yakni dewa yang diharapkan hadir pada 
saat hari suci Saraswati. Hal tersebut jelas adanya suatu nilai pendidikan mengenai bagaimana umat Hindu untuk berusaha mendekatkan diri dan memahami Tuhan melalui pemujaan-pemujaan terhadap aspek-aspek kemahakuasaannya. Adanya mantra ista dewata menunjukkan adanya pernyataan konsistensi keimanan Hindu yang menyatakan Tuhan Maha Kuasa. Ajaran keimanan mengenai Tuhan yang maha kuasa ditunjukkan dengan wujud, nama dan fungsi yang berbeda-beda yang terdapat dalam praktik keagamaan Hindu salah satunya dengan adanya mantramantra ista dewata. Mantra ista dewata memberikan kejelasan, keterfokusan, dan kesederhanaan dalam cara pemahaman terhadap Tuhan sehingga semua kalangan dari stratifikasi masyarakat dari yang tinggi maupun yang rendah, dari yang kaya maupun yang miskin, dari yang tua maupun anak-anak dan lainnya dapat mudah memahami dan berkonsentrasi.

\subsubsection{Sarana Persembahan}

Selain dengan kedua cara tersebut dalam pelaksanaan hari suci Saraswati juga mengunakan pendekatan dengan cara mempersembahkan beberapa sarana persembahan. Sarana persembahan yang dipersembahkan tidak semuanya hanya sekedar persembahan makanan, tetapi berupa banten atau sesajen yang dibuat sedemikian rupa memiliki simbol-simbol yang di dalamnya memiliki makna-makna terkait dengan usaha untuk mendekatkan diri dan pernyataan baik pemujaan maupun tentang permohonan dari orang yang melaksanakan hari suci Saraswati.

\subsection{Catur Guru Dalam Pemaknaan Hari Suci Saraswati}

Hari suci Saraswati sebagai hari ilmu pengetahuan, pembelajaran atau pendidikan akan memiliki kaitan dengan guru. Guru dalam dunia ini dikenal sebagai seseorang yang memiliki pengetahuan dan mengajarkannya kepada orang lain demi membebaskan manusia dari kegelapan atau kebodohan. Ajaran agama Hindu mengajarkan bahwa dalam dunia ini guru terdiri atas Tuhan (Swadyaya), Pemerintah (Wisesa), Guru di sekolah (Pengajian) dan Orang Tua (rupaka) yang disebut dengan istilah catur guru.

\subsubsection{Makna Guru Swadyaya dalam Hari Suci Saraswati}

Hari suci Saraswati menjadi hari pemujaan Tuhan Yang Maha Kuasa dalam fungsinya sebagai pencipta, penguasa dan pemberi pengetahuan 
kepada manusia. Fungsi tersebut telah dinyatakan dalam ajaran Hindu bahwa Tuhan setelah menciptakan alam semesta beserta isinya termasuk manusia kemudian Tuhan tidak membiarkan manusia begitu saja, tetapi Beliau menurunkan ajaran-ajaran tentang bagaimana manusia menjalani kehidupan yang baik dalam dunia ini. Ajaran-ajaran yang diturunkan atau diwahyukan tersebut dinamakan Veda. Kata Veda berasal dari kata Vid yang dapat diartikan mengetahui dan menjadi Veda yang berarti pengetahuan suci (Titib, 1999:13,; Sivananda, 2003:12). Ajaran yang diwahyukan disebut Veda karena memang ajaran-ajaran tersebut berisikan pengetahuan yang komprehensip yang diperuntukkan bagi manusia dalam menjalani kehidupan dalam dunia ini. Meminjam gagasan Gyanshruti dan Srividyananda (2006:30) bahwa" The Vedas contain knowledge of both para and apara vidya...." Ajaran dalam Veda yakni berupa dua jenis pengetahuan yang disebut para dan apara vidya. Meminjam gagasan Titib (1999:30) Veda adalah ajaran yang mendidik umat manusia seharusnya hidup dalam dunia ini. Dengan adanya pengetahuan tersebut manusia dapat menjalani kehidupan dengan baik dan terarah kepada suatu tujuan yang diinginkan. Tuhan menurunkan pengetahuan yang konprehensip melalui para maharsi atau orang suci pada jaman dahulu jelas menunjukkan bahwa Tuhan Maha Pengasih dan Penyayang serta mendidik manusia supaya hidupnya tidak sengsara. Semua hal tersebut jelas bahwa Tuhan merupakan guru bagi alam semesta termasuk manusia yang ada dalam dunia ini.

\subsubsection{Makna Guru Wisesa Dalam Hari suci Saraswati}

Ilmu pengetahuan merupakan suatu aspek kehidupan yang sangat penting dalam kehidupan manusia. Tanpa ilmu pengetahuan manusia akan hidup dalam kegelapan atau kebodohan dan tidak tentu arah dalam kehidupannya. Ilmu penegtahuan menyelamatkan manusia dalam kehidupan ini. Bahkan dalam ajaran Hindu dinyatakan pentingnya ilmu pengetahuan, sehingga dinyatakan manusia mampu menolong dirinya dan juga orang lain dengan ilmu pengetahuan. Ilmu pengetahuan dapat diperoleh bukan saja melalui pendidikan 
informan, dan non formal tetapi juga melalui pendidikan formal.

Dewasa ini, pemerintah telah banyak mengupayakan supaya masyarakatnya mendapatkan suatu pendidikan untuk menambah dan memberikan pengetahuan kepada masyarakatnya. Berbagai macam upaya dilakukan mulai dari menyediakan fasilitas pendidikan baik dari tingkat dasar, menengah pertama, menengah atas, perguruan tinggi. Pemerintah membuka peluang bagi berdirinya dan terlaksananya pendidikan-pendidikan non formal yang dapat dilakukan di dalam masyarakat. Pemerintah selalu melakukan evaluasi dan mengembangkan sistem pendidikan yang tepat dengan melakukan pengembangan kurikulum yang memungkinkan pendidikan menjadi suatu upaya yang dapat diandalkan untuk mengembangkan potensi dan juga menyediakan manusia yang benar-benar berkualitas yang siap dipakai dan bersaing dalam bidangnya. Selain itu pemerintah juga selalu berusaha melindungi masyarakatnya dari berbagai macam hal-hal yang tidak baik. Pemerintah selalu mengupayakan kesejahteraan bagi kehidupan manusia yang ada di bawah pemerintahannnya.

Beberapa contoh karakteristik pemerintah seperti tersebut di atas sehingga pemerintah dinyatakan sebagai guru bagi masyarakat atau manusia. Nilai karakteristik tersebut dapat terlihat juga dalam pelaksanaan hari suci Saraswati. Dewi Saraswati sebagai penguasa ilmu pengetahuan yang merupakan aspek dari kemahakuasaan Tuhan Yang Maha Kuasa telah dinyatakan dalam kitab-kitab suci bahwa Tuhan Yang maha Kuasa selalu mengingatkan kembali manusia pada saat manusia lupa pada ajarannya atau pengetahuan yang telah diberikannya. Menurut Bhalla (2009:42) bahwa" In the Dewi Bhagawat, it is said that Brahma, Vishnu and Mahesh hold Saraswati in great reverence." Makna yang tertuang dalam kalimat tersebut jelas saraswati memiliki peranan dalam pengaturan kehidupan dalam dunia ini termasuk manusia. Brahma, Visnu dan Maheswara atau Siva merupakan aspek Tuhan dalam mengatur dunia ini. Brahma sebagai pencipta, Visnu sebagai pemelihara dan Siva menjalankan fungsi mengembalikan keasalnya segala sesuatunya dalam dunia. Ketiga fungsi tersebut berdasarkan kitab 
Dewi Bhagawata tersebut juga berkaitan dengan Saraswati. Makna yang diperoleh dari hubungan tersebut jelas bahwa dewi Saraswati sebagai simbol ilmu pengetahuan merupakan hal yang penting dalam menjalankan fungsi-fungsi mencipta, memelihara dan mengembalikan keasalnya. Demikian pula dalam pemerintahan sangat diperlukan pengetahuan untuk menciptakan, memelihara dan juga membuat sesuatunya kembali sesuai dengan yang diharapkan atau seharusnya.

\subsubsection{Makna Guru Pengajian dalam Hari Suci Saraswati}

Guru pengajian merupakan orang tua anak dalam pendidikan di luar keluarga. Peran guru pengajian ini sangat terlihat pada pendidikan Veda dimana mengunakan sistem pendidikan gurukula yang berarti keluarga guru. Hubungan siswa dan guru sama seperti hubungan orang tua dan anak dalam menuntut ilmu pengetahuan. Guru pengajian memiliki kemampuan atau pengetahuan dalam bidangnya dan mengajarkannya kepada siswanya tanpa melihat status siswanya. Bahkan guru harus berlaku adil walaupun diantara siswanya ada putranya sendiri. Seorang guru tidak boleh membedakan antara siswanya dan anaknya. Semua siswa diberlakukan secara adil dan sama dan diajarkan pengetahuan dan keterampilan sesuai dengan kemampuan yang dimiliki siswanya. Karakteristik guru pengajian yang sedemikian rupa terlihat dalam makna simbol-simbol dalam perayaan hari suci Saraswati. Dewi Saraswati sebagai sumber ilmu pengetahuan akan memancarkan pengetahuannya kepada siapa saja.

Dewi Saraswati memiliki simbol kesucian atau kebaikan yang harus atau seharusnya dimiliki oleh guru pengajian. Dewi Saraswati memiliki kualifikasi pengetahuan dalam berbagai aspek pengetahuan. Peryataan tersebut tepat karena menurut Bhalla (2009:41) bahwa "Saraswati is the goddess of speech, learning, and knowledge." Saraswati sebagai dewanya ilmu pengetahuan bermakna sebagai penguasa segala jenis pemngetahuan. Oleh karena itu, guru pengajian dalam ajaran Hindu memiliki kualifikasi yang tinggi baik dari karakter maupun pengetahuan.

\subsubsection{Makna Guru Rupaka dalam Hari Suci Saraswati}

Orang tua merupakan salah satu bagian dari catur guru yang terdapat 
dalam ajaran Hindu, yakni disebut guru rupaka. Dalam pelaksanaan hari suci Saraswati nilai-nilai yang mencerminkan guru rupaka sudah pasti ada. Dewi Saraswati memiliki sifat suci dan bijaksana memberikan pengetahuan kepada seluruh umat manusia dengan tulus ikhlas. Dewi Saraswati juga memiliki fungsi yang beragam sehingga juga disebut dengan nama yang berbeda. Amulya dan Bijaya (1993:27) menyatakan bahwa "Saraswati was regarded as a presiding deity of all branches of knowledge, such as fine art, mechanics, and the art of music and dancing." Pendapat yang serupa dinyatakan oleh Kinsley (1988:60) bahwa ada beberapa sebutan Saraswati yakni "Vedagarbhaa (the womb or source of the vedas or knowledge), sarvavidyaasvaruupinii (whose form is all the sciences), sarvasastra." Nilai-nilai karakteristik dari pemaknaan Dewi Saraswati tersebut juga merujuk pada karakteristik guru rupaka atau orang tua. Orang tua dalam agama Hindu dinyatakan sebagai wujud Tuhan dalam dunia ini. Orang tua yang dari awal memberikan tuntunan dan penegetahuan bagi umat manusia. Orang tua yang pertama kali mengenalkan seseorang anak mengenal dunia. Orang tua juga yang mengajarkan berbagai macam pengetahuan, sehingga manusia dapat hidup terarah dan mampu menyesuaikan diri dalam kehidupan masyarakat dan alam lingkungan. Di samping itu, orang tua juga yang memelihara dan menjaga anak dengan penuh rasa kasih sayang yang tanpa pamrih. Dalam memberikan pendidikan anak orang tua menekankan supaya anaknya memiliki pengetahuan, keterampilan dan sikap mental yang baik (Mas, 2002:13). Perbuatan atau tindakan orang tua akan menuntun dan memberikan contoh bagi anaknya dalam dunia ini.

\section{Penutup}

Hari suci Saraswati memiliki nilai-nilai pendidikan Hindu yang tersimpan di balik simbol-simbol yang terdapat dalam Dewi Saraswati maupun dalam pelaksanaan hari suci tersebut. Nilai-nilai pendidikan yang terkandung secara garis besanya terdiri atas 3 (tiga) jenis yakni pendidikan Tattwa yang meliputi teologi atau ketuhanan dan filsafat/filosofis; pendidikan Susila meliputi tiga aspek yakni pikiran, perkataan dan perbuatan; dan pendidikan 
upacara. Dalam pemaknaan hari suci Saraswati terkandung pula makna mengenai catur guru. Makna catur guru tersebut berupa nilai-nilai karakteristik dan aspek-aspek dari guru swadyaya, guru wisesa, guru pengajian dan guru rupaka.

\section{Daftar Pustaka}

Amulya Mohapatra dan Bijaya Mohapatra. 1993. Hinduism Analytical Study. New Delhi : Mittal Publications.

Bhalla, Prem P. 2009. Hindu, Rites, Rituals, Customs and Traditions. New Delhi : Pustak Mahal.

Fadillah, Anisa. 2015. Aktivitas Komunikasi Upacara Adat Hari Raya Saraswati di Bali. (Skripsi). Bandung : Program Studi Ilmu Komunikasi Konsentrasi Jurnalistik Fakultas Ilmu Sosial dan Politik Universitas Komputer Indonesia.

Geertz. Cliford. 1997. Agama dan Kebudayaan. Yogyakarta : Kanisius.

Gyanshruti, Sannyasi and Sannyasi Srividyananda. 2006. Yajna : A Comprehensive Survey. New Delhi : Yoga Publication Trust.

Kinsley, David R. 1988. Hindu Goddesses. California : University of California Press

Mas, A.A.G. Raka. 2002. Menjadi Orang Tua yang Mulia dan Berguna. Surabaya : Paramita
Ngurah, I Gusti, I Gede Sura, I Gede Bajrayasa, Indra Sukarno, I Wayan Mitra Astawa, Sujailanto. 2006. Buku Pendidikan Agama Hindu untuk Perguruan Tinggi. Surabaya : Paramita.

Sivananda, Sri Svami. 2003. Intisari Ajaran Hindu. Surabaya : Paramita

Suhardana, K.M. 2010. Catur Guru Bhakti: Bhakti kepada Empat Guru. Surabaya : Paramita.

Titib, I Made. 1999. Pengantar Veda untuk Program D.II. Surabaya: Paramita.

Suarnada, IGM. 2015. Pemahaman Umat Hindu Tentang Hari Raya Saraswati di Kota Palu Propinsi Sulawesi Tengah. Widya Genitri Volume 7 (1), Desember 2015. 